\title{
The Implementation of Character Values Through History Textbook
}

\author{
Darwati $^{1}$, Sariyatun ${ }^{2}$, Leo Agung Sutimin ${ }^{3}$, Akhmad Arif Musadad ${ }^{4}$ \\ 1,2,3,4 Postgraduate History Education Program Universitas Sebelas Maret, Surakarta Indonesia \\ 1'darwati@student.uns.ac.id, 22sariyatun@staff.uns.ac.id, ${ }^{3}$ leo.agung56@yahoo.co.id, \\ ${ }^{4}$ arif_mussadad_fkip@yahoo.co.id
}

\begin{abstract}
Textbook allocation is one of the methods to improve education quality because the textbook can be used as a resource in developing the quality of human beings. The implementation of character values from the textbook is highly required for the students, therefore the existence of a history textbook is fundamental. The historical textbook contains character values that can be transferred to the students. The goal of this article is to analyze the character values in a history textbook. The result of the study shows that there are character values contained in historical textbooks.
\end{abstract}

Keywords: education, character values, history textbook.

\section{Introduction}

Education is one of the fundamental things in society. It acts as the main propeller of various progression in life. Education can develop the skill and quality of human resources. Without education, the National development would probably be halted. Through times, education tends to develop itself adapting to the environment of society or a nation. Education is one of various means to enacting the values, norms, and tradition for a group of people, also providing the knowledge, lesson, and skill set of those mentioned above to create a figure that excels in character and competency as a human being $[1$, p. 2].

Education can be defined as a conscious and planned activity to provide a conducive learning environment where the students can actively improve their skill and potency to be the part of society, nation, and the country. From a philosophical perspective, education is a process to humanize humans, which can be interpreted that people who received education would strive their life better than those who don't.

The goal of education can be various depends on the person who sees it. Some would say that education is a bridge that connects between a person and his desired job, some others say that education can be used to elevate a person's status. From these various viewpoints, we can say that fundamentally, education is such a noble existence to elevate and strengthen an individual in his role to reach the expectation of society, culture, and religious order. Education should be able to enlighten people to become a true human being and thus, removing any barrier of discrimination among people. Education should provide freedom and positive things to the students.

Character education is a particular characteristic of the 2013 curriculum that had been implemented by the Ministry of Education of Indonesia. Character education was also implemented in the daily learning activities in many schools in Indonesia, from the middle to high school who are using this curriculum. This character-based education is useful to overcome the moral and character issues of the students in this globalization era. 
Moral issues becoming a huge problem in this later generation of the nation, which concerning the future leader of the nation. It would be out of the question if an improper leader which lacks in character is about to run this country. Various problems are hard to deal with the students of Indonesia, such as juvenile delinquency, fist-fighting among students, even the 'simpler ones' like cheating in tests [2]. In this globalization era, character and moral education must be enacted since an early phase, so that the proper character would be built and improved over time.

Character education is highly fundamental to the future generation of Indonesia. The education will not only focus on how the students would process and grasp the information from a lesson but what life-lesson that could be inferred from that. Thus, hopefully, the students would be capable to implement the character values from what they have learned. The implementation of character education is a sincere, systematic, and continuous act to build and strengthen the awareness and possibilities that this nation will not be going anywhere without building a proper character fundamental [3]. That said, character education is widely used in the 2013 curriculum with the vision that it can develop the character of the nation's young, so they can strive into a better future with better capabilities in this globalization era.

The implementation of character education can be done with textbooks. On top of that, history education also provides its usefulness in transferring the character values to the students. To conduct a transfer of values through textbooks, Muhammad Yaumi stated that this strategy is carried out by integrating the character values into textbooks and learning sessions [4, p. 141]. Thus, a textbook is becoming one of the main requirements for implementing character values to the students.

The process of transferring the values through textbooks is carried out in various subjects, like history in this particular topic. A textbook is a medium to deliver the lesson of a particular subject. It goes the same way with history textbooks which are also used by the teachers as a source of material for their class. The subject itself contains the character values from the stories of past events, this means that these character values could also be implemented to the students.

\section{Method}

This article is a descriptive research with qualitative approach in which the researcher acts as the main instrument [5, p. 185]. The data is collected through literature study, namely history textbooks. As of the analysis technique this research employs the Interactive Analysis method [6, pp. 19-20] which process is comprised of data collection data reduction, data presentation and verification/ conlusion.

\section{Result And Discussion}

Education is a conscious act, carried out by people to provide themselves a higher thinking capability, which also acts as fundamental of living and interacting with other people. It means that education is one of the methods to develop the character of a human being. This also means that education would build a stronger sense of dignity which then leads to improvement in personality to become a true human being. 
Along with the development of science, education is also experiencing a dynamic process to counterfeit with various given conditions and situations. The education has experienced various changes in curriculum and conducted various means to reach the National Education goals that were written in the 2003 Regulation No. 20 about the National Education System, one of the innovations is to conduct the character education through various education processes.

In Indonesia, education is divided into several levels, each one providing different subjects. Usually, there are particular goals required in every subject, to identify the succession rate of the given subject. The fundamentals of education are used to compile the required goals for the subjects [7, p. 22].

Character education already exists since the Ancient Greek civilization. To this day, it is still being promoted that the term 'character education' is no longer sounds unfamiliar to the education communities in Indonesia. According to Jhon Dewey, it is a common thing in theories about education, that the common goal of character education is the development of fine personality. But it should be underlined that character education is not merely relied on religion and moral education. Character education is also formed in another type, which comes from the understanding or defined from the personality of a person [8, p. 299].

The term 'character' becoming more and more familiar to Indonesian citizens each day. This means that character education already gains its recognition among the people. It also comes from the various issues in the outcome of Indonesia's education system, such as the misdemeanor of the people who possess a higher education but still caught red-handed on corruption, violence, even free sex, and drugs. This makes people think that character education is one of the methods that can be applied to this country.

Character education defines the learning process as a means that purposed on strengthening and developing the whole character of a child, based on the particular value proposed by the school [9, p. 22].

Lickona stated that character education should introduce the cognitive value (moral knowing), the affective appreciation of the value (moral feeling), and direct action to implement the value (moral action) to the students [10, p. 51]. From Lickona's statement, it can be inferred that all of the subjects in schools must contain character values, thus it can bring the students to become the true human being.

To implement the character values with the media of the textbook, Muhammad Yaumi stated that the strategy of developing a character-based textbook is a means of compiling and creating textbooks by integrating the character values into the textbook and to the class activities. Each of the textbooks contains character values that can be taught to the students [4, p. 141]. History textbooks are no different, they contain character values that also can be transferred to the students.

Marzuki stated that there should be adaptations from the textbooks that the teacher must do during their class. The most possible adaptation is by conducting an integrative learning session that can be simultaneously developing the character. The other method is by adapting or changing the learning session based on what the textbook is used. This kind of adaptation is done by revising the core substance of the lesson [11, p. 41].

Widodo stated that a textbook can be read everywhere, whenever possible, and can be used according to the development of the curriculum [12]. Emphasized by the National Law of Ministry of Education No. 11, 2005, textbooks are mandatory sources to be used in schools, containing various learning materials in purpose to improving the religious values, character, and personality, science, awareness, ethics, physical and vitality potencies that are compiled based on the national education standards. 
Textbooks becoming a versatile media and learning source that plays an important part in reaching the competencies as a purpose of the learning process. The right choice and utilization of the textbooks as a source of learning material plays an important part in carrying out the learning process.

Each subject requires textbooks as a form of guide (handbook). It also goes for history. Textbooks contain particular objectives to help students understanding the contents of the book more easily. They provide some features such as schemes, diagrams, matrix, illustrations, and some more other to help students understanding the topic inside. Textbooks also help teachers to deal with the requirements of the curriculum, particularly with the teaching programs such as components for the teaching material, syllabus, and the teaching preparation itself.Learning about history is not only about understanding the past events, or creating a critical thinking process as well as improving the historical skills but also to improve the capability of receiving the meaning and values from the past events. These historical values can be utilized to grow the character values in the students.

History becoming one of the subjects taught at schools. History is an explanation and understanding of past events, as a reflection for today and can be utilized to predict the upcoming events. [13] explained that there are two dimensions of historical benefit, one is intrinsic and one is extrinsic. Intrinsic means that history is highly beneficial to the development of science particularly to the history science itself. While the extrinsic means that history inspires the journey of humankind.

The purpose of history education divided into three aspects, such as:

a. Knowledge aspect, including the purpose of history to transfer knowledge and understanding about something valuable from the past;

b. Attitude improvement aspect, in the form of inheritance of the values which can be obtained from the past events that can be a guide to act more wisely;

c. Skill aspect, that adapted from the reformation of historical teaching, a new principle of active learning.

With this principle, hopefully, the history class could develop skills in containing historical evidence, questioning and discussing historical issues, reviewing history literature, and can lively tell stories about historical events. The character values that can be obtained from the historical process are possibly come from these sources (1) the discussion about historical fundamentals, (2) the benefit of learning history, (3) the purpose of learning history, and (4) the history textbooks and the topics within it. The implementation of character education to the students can be carried out through the history sessions. Character values are available in every subtopic of history. Historical events written in the textbooks contain character values that can be implemented either directly or indirectly by the students. Some of the character values that were mentioned are religious values, tolerance, nationalism, and peace.

The historical events that were written inside the textbooks also provide some implicit character values that can also be enacted by both the students and the teachers. These values could also be re-enacted by giving evaluation after studying the history textbooks and obtained the wisdom from understanding the history textbooks.

\section{Conclusion}

Character values in education in Indonesia are incredibly important. The implementation of character education to the students can lead to the future generation that has quality as a 
person and a high moral standard. The learning session of history is not only for creating critical thinking and historical skills but also to improve the capability to receive the meaning and values contained in a particular historical topic. The historical values can be represented in the form of character values to build an Indonesian citizen with high moral standards.

The learning session filled with the history theme goes well with the 2013 curriculum, which not only exists to achieve the cognitive competency and skill but also to achieve the attitude competency. The attitude competency comes from the nurturant effect from the direct teaching about knowledge and skill. This meaningful learning session can use various learning models, as long as the model would strengthen the scientific approach and actively involve the students in the process. The implementation of values in the learning process can be seen from the group discussion in their activities to solve and discuss the issues or problems given by the teacher based on the syntax of the learning model.

\section{References}

[1] C. S. A. Jabar, Manajemen Pendidikan. Yogyakarta: UNY PRESS, 2016.

[2] A. Y. Sobri, "Sekolah Dasar: Kajian Teori dan Praktik Pendidikan," Sekol. Dasar Kaji. Teor. dan Prakt. Pendidik., vol. 24, no. 1, pp. 18-25, 2017.

[3] A. Kautsar and J. Edi, "Pendidikan Karakter Religius, Disiplin Dan Bakat Melalui Penigkatkan Kualitas Sarana Prasarana Sekolah,” JMKSP (Jurnal Manajemen, Kepemimpinan, dan Supervisi Pendidikan), vol. 2, no. 2, pp. 259-278, 2017, doi: 10.31851/jmksp.v2i2.1475.

[4] M. Yaumi, Pendidikan Karakter Landasan, Pilar \& Implementasi. Jakarta: Prenadamedia Group, 2014.

[5] J. W. Creswell, Research Design: Qualitative, Quantitative, and Mixed Methods Approaches. Singapura: SAGE, 2014.

[6] B. M. Miles and M. Huberman, Analisis Data Kualitatif Buku Sumber Tentang Metode-Metode Baru. Jakarta: UIP, 1992.

[7] D. Siswoyo, Ilmu Pendidikan. Yogyakarta: UNY PRESS, 2013.

[8] F. Mu'in, Pendidikan Karakter: Konstruksi Teoritik dan Praktik. Yogyakarta: Ar-Ruzz Media, 2013.

[9] D. Kesuma, Pendidikan Karakter Kajian Teori dan Praktik di Sekolah. Bandung: Remaja Rosdakarya, 2011.

[10] T. Lickona, Educating for Character: How Our Schools Can Teach Respect and Responsibility A Bantam trade paperback, Reprint. New York, Toronto, London, Sydney, Aucland: Bantam Books, 1992.

[11] Marzuki, "Intergating character education in the teaching and learning at school," J. Pendidik. Guru Sekol. Dasar, vol. 2, no. 1, pp. 33-44, 2012.

[12] T. Widodo, "Tingkat Keterbacaan Teks: Evaluasi Terhadap Buku Teks Ilmu Kimia Kelas I SMA,” IKIP Jakarta, 1993.

[13] Kuntowijoyo, Pengantar Ilmu Sejarah. Yogyakarta: Yayasan Bentang Budaya, 1995. 